\title{
INTERVIEW WITH XAVIER ALDANA REYES ${ }^{1}$
}

André Cardoso (UFF)

Ana Resende (UFF)

Recebido em 08 mai 2020. André Cardoso is associate professor of EnglishAprovado em 23 mai 2020. Language Literatures at Universidade Federal Fluminense (UFF).

André Cardoso é Professor associado de Literaturas de Língua Inglesa na Universidade Federal Fluminense (UFF).

Ana Resende is an English Literature graduate student at Universidade Federal Fluminense (UFF).

Ana Resende é Mestranda em Estudos de Literatura na Universidade Federal Fluminense (UFF), sob orientação do Prof. Dr. André Cardoso.

1 The translated version, into portuguese, is available at the end of the original version. / A versão traduzida, para o português, está disponível ao final da versão original. 


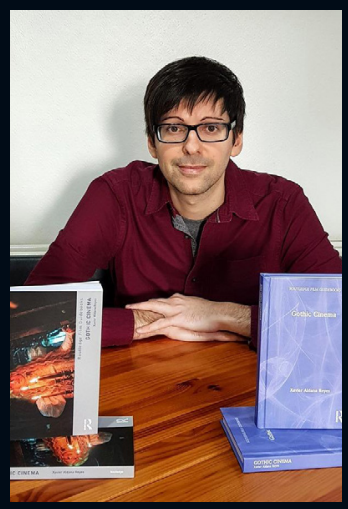

Xavier Aldana Reyes is Reader in English Literature and Film in Manchester, a founding member of the Manchester Centre for Gothic Studies, and the author of Spanish Gothic: National Identity, Collaboration and Cultural Adaptation (2017) and Gothic Cinema (2019). His publications in Gothic and horror studies include Twenty-First-Century Gothic: An Edinburgh Companion (with Maisha Wester; 2019), Horror: A Literary History (2016) and Digital Horror: Haunted Technologies, Network Panic and the Found Footage Phenomenon (with Linnie Blake; 2015). Aldana Reyes also edited fiction anthologies for the British Library series, Tales of the Weird, including the following titles: The Gothic Tales of H.P. Lovecraft (2018), The Weird Tales of William Hope Hodgson (2019), Promethean Horrors: Classic Tales of Mad Science (2019) and Roarings from Further Out: Four Weird Novellas, by Algernon Blackwood (2019).

Q.: In your book Spanish Gothic: National Identity, Collaboration and Cultural Adaptation (2017), you explore how the understanding of the Gothic in Spain helps us to understand the Gothic mode in a global context, as a transhistorical, transnational and transmedia phenomenon. During your research, did you have an opportunity to study the Gothic in other Spanish- or Portuguese-speaking countries? Could you tell the readers about the challenges of working with foreign literature in an Anglophone academic community?

A.: I am sure there are some affinities between Portuguese- and Spanish-speaking countries in their development of their own forms of the Gothic mode, even if just because their writers, filmmakers and artists have tended to work from the relatively "un-Gothic" context of sun-bathed lands. Unfortunately, I have 
only had the opportunity to explore the history of the Gothic in Iberian Spain, but would love to read similar histories of the Gothic in Brazil, Mexico or Portugal, some of which I am pretty sure are being written as we speak. As you say, the way I read the Gothic in Spanish Gothic is quite modern: I am less interested in what terms may have been used to identify certain forms of dark literature in the past than the possibilities opened up by an outlook that builds bridges between cultures which were in some cases patently influenced by each other. Inevitably, there will always be some protective gatekeeping - this is understandable, and I never want to suggest that we should not be attuned to the specificity of national or regional inflections of modes and genres. At the same time, we live in a global, hyperconnected world marked by synergy and cross-fertilisation of ideas. Some have even pointed out the eminently transnational nature of many blockbusters made in the twenty-first century, and I often find myself reading way beyond England and America in my attempt to keep up with what is going in the Gothic. It's wonderful that the mode has been decentralised in this way and that there is an effort to recuperate less well-known Gothic manifestations. Spain has been perceived as a setting, rather than a country that created the Gothic, its projected vicious Catholicism and the exacerbated passions of its people ideal for the type of excessive scenarios that interested a Protestant England. My main goal with Spanish Gothic was to introduce Spain as a creator of the mode too.

The biggest challenge that faces anyone seeking to write any type of national genre history is what to do with 
complex territorial issues that naturally impinge on notions of identity and culture. For example, I have a PhD student, Rebecca Wynne-Walsh, who has just started a doctoral dissertation on Basque Gothic cinema. Her thesis is very powerful: what types of national discourses are activated by attempts to homogenise what, in the case of Spain, is a rather varied set of "comunidades autónomas" (autonomous communities, i.e. political and administrative divisions), with specific characteristics and histories? Due to its scope, I wasn't really able to do more than hint at this plurality in my book. The scars of the Spanish Civil War (1936-39) and Franco's subsequent dictatorship have made it rather easy to think of Spain as a country united in its struggle against oppressive governing forces, but this runs the risk of erasing regionalism. Perhaps Catalan and Basque Gothic share a number of concerns that manifest at the level of comparable struggles for political representation or the importance of language to formations of identity, especially as a form of resistance. Yet they are also very different: Basque folklore is unique and very different from Catalan myths and traditions. This is always something difficult to articulate and capture well, especially for an academic community who, inevitably, will be outsiders to them. Simultaneously, the communities represented in studies of the Catalan or Basque Gothic might not always have access to English or feel comfortable speaking it, which further highlights both the impact and limitations of working in/through linguistic and cultural translation. 
Q.: In Spanish Gothic, you invite the readers to rethink Spanish Gothic against the tendency of the critics to ignore the Gothic in Spain. Professor Júlio França, in an article called "The Sequestration of Gothic in Brazil" (2017), speaks in similar terms of the "erasure of Gothic" by the Brazilian literary criticism of the first half of the $19^{\text {th }}$ century, which favored "realistic works and those works in an explicit and direct connection to the questions of a national identity (p.113)". Could you explain the importance of critical and historiographical studies that reclaim the Gothic as a "form of cultural adaptation (p.10)" and to what extent we can talk about specific national forms of Gothic, which differ from the Gothic in the Anglo-Saxon tradition?

A.: This is a very good question, and one to which I perhaps only partially articulated in my book. To a certain extent, it is perfectly natural that the term "Gothic" was not, until recently, widely used in the context of Spanish letters: other terms, like "lo fantástico" or "literatura de terror", have been used to define similar forms of fiction, and some critics before me, like David Roas or Miriam López Santos in Spain and Abigail Lee Six or Ann Davies in the UK, had indeed begun to apply the term too. But this critical turn is really quite recent, in many cases only really apparent in the last ten years, which have been coloured by a turn to the Gothic as important artistic and critical set of tools in academia. I see my book as an invitation to consider the areas of overlap between the Spanish and the English Gothic as more than simple cases of copycat and as an attempt to focus on the specifics of the Gothic as a mode 
with aesthetic traits (an obsession with the past, decay and death, with the projected past, with supernatural horror) and emotional interests (the emphasis on dread, suspense and horror). For me, "lo fantástico" is too conceptual a term and I don't find it very user-friendly, and "horror" defines a genre that has wider aesthetic cues. I have tried to further delimit the Gothic in more recent work.

In Spanish Gothic, I make two key points: one is that the country did have a history of supernatural fiction, sometimes used for horrific effect, before the development of the English Gothic novel in the late eighteenth century. I even mention how the "novella cortesana" already exhibited some of the aesthetic preoccupations of the English Gothic. Crucially, though, the Gothic caught on after the publishing furore that took Europe by storm in the late eighteenth century, and entered via France - both in the shape of French translations of Gothic novels and of Spanish translations from the French. To me, this process of mediation is particularly fascinating. As López Santos explores in her indispensable La novella gótica en España (2010), the process of cultural translation that underlies the introduction of the Inquisitionsanctioned Gothic novel in Spain is a great barometer for the country's moral understanding of the role of prose in the early nineteenth century. I don't just mean that it is interesting to think through which writers made it through the heavy religious censorship (Ann Radcliffe, Regina Maria Roche) but also to consider what happened to the texts themselves: what was kept, transformed and removed. As the 
Gothic becomes something to render visually in twentiethcentury Spain, we observe a similar desire to adapt the mode's imagery for new and modern audiences on the part of filmmakers: the titillating subtexts of the Gothic come to the fore in the 1960s and 1970s, a period of dramatic change for Spain and of gradual cultural opening. This is the second important point I make, namely, that the realist mode that is seen as the country's preferred literary register is itself a critical construction, and perhaps one that sometimes masks a certain conservativism. The Gothic, especially in its playful rendition of the numinous and supernatural, clearly allowed for the exploration of ideas that would otherwise have remained taboo. The case of Alfonso Sastre, whose work was often very political and frustrated by censorial intervention, is a good case in point.

Q.: In the introduction to Horror: A Literary History, you call horror "the genre par excellence" because it exploits negative emotional states "like dread, shock or abject repulsion (p.12)" in a social and/or personal level. Could you tell the readers more about this characteristic of horror and how do Gothic and horror differentiate from each other?

A.: The distinction between the Gothic mode and the horror genre is one I have been trying to untangle since I wrote the lines you quote. I think I have done a more thorough job in the introduction to Gothic Cinema $(2020)^{2}$ and in an article I wrote last year for the Oxford Research Encyclopedia of Literature ${ }^{3}$. In

2 Link to the page where the book can be found: https://www.routledge.com/GothicCinema-1st-Edition/Aldana-Reyes/p/book/9781138227569

3 Link to the page where the article can be found: https://oxfordre.com/literature/ 
short, though, I believe that "horror" is a genre defined by the emotional state it seeks to engender, roughly speaking "horror" or "fear". Within these, there are subcategories: some texts will aim to unsettle in a less confrontational way, say by suggesting, rather than describing the source of threat; others will confront readers and characters with them directly or focus on pain and carnage; yet others will emphasise the disgusting side of fear. Horror, crucially, can manifest anywhere and at any point in time: it is possible to have horror texts set in space, in the Wild West or underwater. By contrast, the Gothic is more bound to a specific time and place, generally a fantastic projection of the past. Its temporal markers, often connected with decay, stagnation and return, are crucial for the type of work it carries out (see below). The Gothic can be usefully understood as a phase in horror fiction that has continued into the present (hence why some will speak of "Gothic horror"). The fact that many of the classic horror films from Universal and Hammer found inspiration in literary Gothic texts has further muddled the ground. Both now share many atmospheric primers (storms, atmospheres), characters (supernatural monsters, tyrants) and motifs (hauntings, forbidden or found texts). Yet I think they can be productively separated. I know that this is not necessarily the most popular definition of the Gothic, which is increasingly being seen as the dark side of culture and as encompassing anything from horror to dark science fiction and even fantasy. I do, however, find it a more intuitive taxonomy and one that allows us to separate aesthetics from artistic effects.

view/10.1093/acrefore/9780190201098.001.0001/acrefore-9780190201098-e187 ? rskey=xFSelf\&result $=1$ 
Horror, as a dark form of art that explores that which is normally unacknowledged, taboo, rejected, repressed or feared, is by its very nature one of the most honest artistic genres; I'd even go as far as to say one of the most human. To study the history of the horror genre is to think through societal preoccupations across generations, to identify a move from religious and atavistic fears to, most recently, the challenges mounted by neoliberalism, the rise of the alt right or the climate crisis. As for the Gothic, I think its obsession with the past, especially its traumatic return in the form of curses, hallucinations and even hereditary illnesses, strikes me as naturally posed to explore the scars of personal and national traumas. From Usher to the often indeterminate apparitions connected to antiquarian objects in M. R. James and on to the horrors of the Spanish Civil War in the cinema of Guillermo del Toro, the language of repression and acknowledgement, of restitution and revenge, lends itself to the exorcism of personal ghosts and to national reparation. The retrojection of the Gothic into the Victorian or Edwardian periods or to proxy buildings signals the tensions between what we often construct as the barbaric past, especially in terms of social struggle, and the more modern present. The Female Gothic channels these concerns particularly well: the Gothic castle and mansion often stand in for ossified notions of patriarchy, for an oppressive mode of control the heroine must find a way to navigate and escape.

Q.: In The Gothic Body: Sexuality, Materialism, and Degeneration at the Fin de Siècle (1997), Kelly Hurley talks about a cyclical resurgence of Gothic at periods of social and epistemological 
crisis. More than twenty years after the release of her book, we're living through a period of crisis. In your opinion, are we also witnessing a re-emergence of the Gothic? What forms is it taking?

A.: Maisha Wester and I have recently tried to tackle this huge issue in a collection entitled Twenty-First-Century Gothic: An Edinburgh Companion $(2019)^{4}$, where we look at the contemporary Gothic from various pertinent angles. The transnational aspect of the Gothic, which I have covered already so will leave aside, is important, but others that strike us as worth covering are the capacity of the Gothic to mediate anxieties around climate change and the impact of human behaviour on the environment (Ecogothic), around the status and place of the human in an age defined by breakneckspeed technological development (posthuman Gothic), new digital platforms and instant communication (digital Gothic), and rampant free market economics (neoliberal Gothic). The Gothic's monsters have adapted to carry out this type of cultural work too, so arguably the zombie and the vampire now more readily convey fear around the danger of pandemics in a hyperconnected world or the ways in which certain bodies and communities continue to be socially abjected. Admittedly, this collection relies on a more capacious understanding of the Gothic mode - the one I was hinting at in my previous answer - whereby the Gothic becomes a means through which to channel social, political, economic and ecological concerns. I think what seems undeniable is that, after a relatively quiet 4 Link to the page where the book can be found: https://edinburghuniversitypress.com/ book-twenty-first-century-gothic.html 
period in the 1990s, the Gothic came back with a vengeance in the twenty-first century. Some will undoubtedly read this as a response to important historical events like the terrorist attacks on the World Trade Centre and the 2008 economic crisis. I would agree with this in part, but I also think the Gothic has come back because of market forces connected to globalism and to successful trends - think, for example, of the rise of paranormal romance following the success of Stephenie Meyer's Twilight novels and their film adaptations.

Q.: You have just released Gothic Cinema (2019). Could you tell the readers more about this book? Do you see an evolution of Gothic in visual narratives over the past decades? And in which way do these narratives call the Gothic tradition into question?

A.: My main aim with the project that has culminated in Gothic Cinema was precisely to mount a defence of Gothic cinema as an aesthetic mode with a distinctive set of markers that can be disentangled from horror. It has been more actively driven by the specificity of the cinematic medium and of the Western film industry: when did the Gothic begin to manifest on screen, and was this a self-aware process? When and why did film begin drawing on, even creating, a Gothic aesthetic comparable to that of the literary tradition? Are monsters or the supernatural a requisite of the Gothic? Once a world of shadows, what happened to Gothic cinema when Hammer and other studios began bathing their period films in glorious technicolour? And what happened to the Gothic once the exploitation boom of the 1960s and 1970s and the success 
of the more realist and contemporary horror popularised by The Exorcist (1973) rendered its settings and titillating subtexts passé, even redundant? The historical drive behind these burning questions was significantly emboldened by a grant I was awarded by the British Academy and the Leverhulme Trust in 2018 to visit key film archives in the States - the Library of Congress (Washington) and the Margaret Herrick Library (Los Angeles) - to consult existing photographic material for many lost Gothic films from the 1910s and 1920s.

I only started properly writing what would become Gothic Cinema in 2016, but its gestation period goes much further back. I have had a long academic fascination with the Gothic since I undertook my MA programme and subsequent $\mathrm{PhD}$, and of course, I now belong to the Manchester Centre for Gothic Studies and teach BA and MA Gothic units at Manchester Metropolitan University. In a sense, thinking about Gothic cinema is something I cannot help but do on a weekly basis. Yet two moments were key in sparking the final creative fuse. The first of these was an invitation I received to give a paper at the aforementioned Gothic season at the BFI in 2013. When the organisers asked me if I had a book on the subject they could promote, it suddenly hit me that I probably could and definitely should. The second wake-up call came while codelivering with $\mathrm{Dr}$ Linnie Blake the 'Introduction to Gothic Cinema' course at Cornerhouse (now HOME) in the autumn of 2014. The experience was transformative and the excitement of the attendees truly infectious. Once more, I had to reply in the negative when people asked me if there was something 
I had written on the topic they could read and, once more, I thought to myself that there was no good reason for this. Fastforward to 2020 and I now have produced that book. Part of academic writing, though, is never feeling quite satisfied with anything you've written, so I have other connected projects I can't wait to develop. This is my first, but certainly not my last (health permitting), word on the relevance of the Gothic as a cinematic aesthetic.

Q.: You've also edited the works of H.P. Lovecraft, William Hope Hodgson and Algernon Blackwood, among others. How do you choose what stories will go into the books? Could you describe your working process as an editor of fiction anthologies?

A.: I'd want to be very careful in pointing out that I've mostly selected, rather than strictly edited the work of these writers. I am a huge admirer of Lovecraft, Hodgson and Blackwood, but I simply don't have the author-specific expertise that, say, someone like S. T. Joshi has and which is necessary for actually editing their fiction. However, I do believe the work of anthology editors is a very important one. I, for example, was introduced to the work of many horror and Gothic writers through collections by the likes of Stephen Jones and Mike Ashley. If done well, anthologies can be important books in their own right.

When the British Library asked me about the possibility of editing Lovecraft, I jumped at the idea. He had always been a favourite and I felt that there was an opportunity to offer something different by focusing on the most Gothic of his 
tales. Hodgson and Blackwood, as well as Promethean Horrors: Classic Tales of Mad Science, were proposed by myself as follow-ups that would fit the Tales of the Weird series, of which I am an avid follower. My thinking behind the anthologies has always been to offer something that is introductory at heart (so I've always gone for my favourites or the stories that I think deserve more credit) and a little different. This was particularly important to me with regards to the mad science anthology: I wanted to create the book l'd always wanted to buy, a collection of the best mad science tales, but which I'd never been able to find. If nothing else, these anthologies offer affordable first insights into writers that might still be new to many. One of the pleasures of my job as a teacher is to introduce students to new texts they may have never otherwise encountered, so I see my work as anthology editor as an extension of it.

\section{Q.: As a founding member of the Manchester Centre for Gothic} Studies, could you tell us something about the Centre, its activities and plans for the future?

A.: The Manchester Centre for Gothic Studies, founded in 2013, is a research hub that concentrates on the multifarious manifestations of the Gothic mode, from its crystallisation around literature towards the end of the eighteenth century to modern video games and other forms of popular culture. Our mission is to promote the study of the Gothic both nationally and internationally and to work across age ranges and levels of study - from sixth form to PhD and beyond. To do this we have run study days, creative writing workshops and Continuing Professional Development courses. We have run city-wide 
Gothic festivals, networking days and research lectures, often in collaboration with a range of partners across Manchester and the UK, that have helped us not only showcase our work but bring the dark delights of Gothic culture to a wider nonspecialist audience. In 2018, we hosted the 14th conference of the International Gothic Association, the most significant gathering of Gothic academics in the world. We have also developed a new digital platform, HAUNT Manchester, that centres on the city's dark cultural offer.

Our focus for the future is to continue to grow our international reach through our activities and collaborations. Gothic Manchester will be running for its eighth consecutive year in October (I am afraid I can't give you any details on content at this point) and HAUNT Manchester will begin to branch out into other cities soon. It is all very exciting! As for myself, I am running an 8-week public course with HOME cinema in Manchester (January to March 2020) to promote the publication of Gothic Cinema and running an online campaign using the Twitter hashtag \#gothicinema366 (my handle is @XAldanaReyes). My intention is to tweet about a different Gothic film included in the book for every day of the year. Fingers crossed, I get through them all!

\section{Q.: Xavier Aldana Reyes, we would like to thank you for taking your time to answer these questions. Would you like to share something else with the readers?}

A.: No, I think I have taken up enough of their time! I simply want to thank them for reading and to thank you for this wonderful and well-researched interview. It has been an absolute pleasure on my part. Muito obrigado! 


\section{ENTREVISTA COM XAVIER ALDANA REYES}

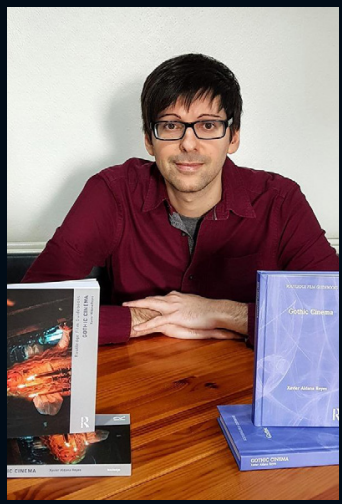

Xavier Aldana Reyes é professor de Literatura e Cinema Ingleses em Manchester, membro fundador do Manchester Centre for Gothic Studies e autor de Spanish Gothic: National Identity, Collaboration and Cultural Adaptation (2017) e Gothic Cinema (2019). Nos últimos anos, organizou diversas publicações acadêmicas, incluindo Twenty-First-Century Gothic: An Edinburgh Companion (com Maisha Wester; 2019), Horror: A Literary History (2016) e Digital Horror: Haunted Technologies, Network Panic and the Found Footage Phenomenon (com Linnie Blake; 2015), além de editar coletâneas e antologias de ficção para a coleção "Tales of the Weird", da British Library, incluindo os títulos: The Gothic Tales of H.P. Lovecraft (2018), The Weird Tales of William Hope Hodgson (2019), Promethean Horrors: Classic Tales of Mad Science (2019) e Roarings from Further Out: Four Weird Novellas, de Algernon Blackwood (2019).

P.: Em seu livro, Spanish Gothic: National Identity, Collaboration and Cultural Adaptation, de 2017, você explora como a compreensão do Gótico na Espanha nos ajuda a compreender o modo Gótico em um contexto global, como um fenômeno transhistórico, transnacional e transmídia. Durante a sua pesquisa, você teve a oportunidade de estudar o Gótico em outros países de língua espanhola e portuguesa? Você poderia falar sobre os desafios de trabalhar com literatura estrangeira em uma comunidade acadêmica de língua inglesa?

R.: Eu tenho certeza de que existem afinidades entre os países de língua portuguesa e espanhola no desenvolvimento de suas próprias formas do modo Gótico, mesmo que seja pelo fato 
de que seus autores, cineastas e artistas trabalharam a partir do contexto relativamente "não Gótico" de países iluminados pelo sol. Infelizmente, eu só tive a chance de explorar a história do Gótico na Espanha Ibérica, mas adoraria ler histórias do Gótico semelhantes no Brasil, México ou em Portugal, algumas das quais eu tenho certeza de que estão sendo escritas neste momento. Como vocês dizem na pergunta, o modo como eu leio o Gótico em Spanish Gothic é bastante moderno: estou menos interessado em quais termos foram usados para identificar certas formas de literatura sombria no passado do que nas possibilidades abertas por uma perspectiva que constrói pontes entre culturas que, em alguns casos, foram nitidamente influenciadas umas pelas outras. É inevitável que sempre haja algum mecanismo de proteção - isso é compreensível, e eu nunca pretendi sugerir que nós não deveríamos estar atentos à especificidade das inflexões regionais ou nacionais dos modos e dos gêneros. Ao mesmo tempo, nós vivemos em um mundo globalizado, hiperconectado, marcado pela sinergia e fertilização cruzada de ideias. Alguns pesquisadores até destacaram a natureza eminentemente transnacional de muitos blockbusters do século XXI, e frequentemente eu me vejo lendo muito além da Inglaterra e dos Estados Unidos na minha tentativa de acompanhar o que está acontecendo no Gótico. É incrível que o modo tenha sido descentralizado dessa forma e que haja um esforço para recuperar manifestações Góticas menos conhecidas. A Espanha foi considerada um cenário, mais do que um país que criou o Gótico; o nefasto Catolicismo que lhe é projetado e as paixões exacerbadas 
do povo eram ideais para o tipo de cenários excessivos que interessava à Inglaterra protestante. Meu objetivo, com Spanish Gothic, era introduzir a Espanha também como uma criadora do modo.

O maior desafio para quem quer escrever qualquer tipo de história de gênero nacional é o que fazer com questões territoriais complexas que naturalmente influenciam as noções de identidade e cultura. Por exemplo, tenho uma orientanda de doutorado, Rebecca Wynne-Walsh, que começou a escrever uma tese sobre o cinema gótico basco. A tese dela é muito poderosa: que tipos de discursos nacionais são ativados por tentativas de homogeneizar aquilo que, no caso da Espanha, é um conjunto bastante variado de comunidades autónomas (comunidades autônomas, isto é, divisões políticas e administrativas) com características e histórias específicas? Devido ao escopo da pesquisa, eu não fui capaz de fazer mais nada, além de apontar para esta pluralidade no meu livro. As cicatrizes da Guerra Civil Espanhola (1936-39) e da posterior ditadura de Franco tornaram bastante fácil pensar na Espanha como um país unido em sua luta contra a opressão das forças governamentais, mas assim corre-se o risco de apagar o regionalismo. Talvez o Gótico catalão e o basco compartilhem algumas preocupações que se manifestam no nível de esforços comparáveis por representação política ou da importância da língua para formações de identidade, sobretudo, como forma de resistência. No entanto, também são muito diferentes: o folclore basco é único e muito diferente dos mitos e tradições catalães. Isso sempre é algo difícil de articular e capturar 
bem, sobretudo, para uma comunidade acadêmica que inevitavelmente estará alheia a isso. Ao mesmo tempo, as comunidades representadas em estudos do Gótico catalão ou basco talvez nem sempre tenham acesso ao inglês ou fiquem à vontade falando o idioma, o que também evidencia o impacto e as limitações de trabalhar em/através de traduções linguísticas e culturais.

P.: Em Spanish Gothic, você convida os leitores a repensarem o Gótico espanhol contra a tendência dos críticos de ignorar - Gótico na Espanha. O prof. Júlio França, em um artigo intitulado "O sequestro do Gótico no Brasil", de 2017, fala em termos semelhantes do "apagamento do Gótico" pela crítica literária brasileira da primeira metade do século $\mathrm{XIX}$, que favorecia "obras realistas e aquelas explícita e diretamente relacionadas às questões de identidade nacional (p.113)". Você poderia explicar a importância de estudos críticos e historiográficos que recuperam o Gótico como uma "forma de adaptação cultural (p.10)", e em que medida nós podemos falar de formas nacionais específicas do Gótico, que diferem do Gótico na tradição anglo-saxã?

R.: Esta é uma pergunta muito boa, e foi uma questão que eu talvez só tenha articulado parcialmente no livro. Em certa medida, é perfeitamente natural que o termo "Gótico" não fosse, até recentemente, usado de modo amplo no contexto das letras espanholas: outros termos, como "fantástico" ou "literatura de terror", foram usados para definir formas semelhantes de ficção, e alguns críticos antes de mim, como David Roas ou Miriam López Santos, na Espanha, e Abigail Lee Six ou 
Ann Davies, no Reino Unido, começaram, na verdade, a usar o termo também. Mas esta virada crítica é realmente muito recente; em muitos casos, só se tornou aparente nos últimos dez anos, que foram marcados por uma volta ao Gótico como um conjunto de ferramentas artístico e crítico importante na academia. Eu vejo meu livro como um convite para considerar as áreas de sobreposição entre o Gótico espanhol e o inglês como mais do que simples casos de imitação e como uma tentativa de focar nas especificidades do Gótico como um modo com traços estéticos (uma obsessão com o passado, decadência e morte, com o passado projetado, com o horror sobrenatural) e interesses emocionais (ênfase no terror, suspense e horror). Para mim, "fantástico" é um termo muito conceitual e eu não o considero fácil de usar, e "horror" define um gênero que tem sugestões estéticas mais amplas. Eu tentei delimitar mais o Gótico em obras mais recentes.

Em Spanish Gothic, eu observo dois pontos essenciais: primeiro, que o país tinha uma história de ficção sobrenatural, às vezes, utilizada para efeito horrorífico, antes do desenvolvimento do romance Gótico inglês no fim do século XVIII. Eu até menciono como a novela cortesana já apresentava algumas das preocupações estéticas do gótico inglês. Mas, de modo decisivo, o Gótico se tornou popular após o furor editorial que tomou a Europa no fim do século XVIII e entrou via França tanto na forma de traduções francesas de romances góticos quanto de traduções espanholas a partir do francês. Para mim, este processo de mediação é particularmente fascinante. Como López Santos explora no indispensável La novella gótica 
en España, de 2010, o processo de tradução cultural que está na base da introdução do romance gótico sancionado pela Inquisição na Espanha é um grande barômetro para a compreensão moral do país a respeito do papel da prosa no início do século XIX. Não me refiro apenas ao fato de ser interessante pensar quais escritores conseguiram passar em meio à pesada censura religiosa (Ann Radcliffe, Regina Maria Roche), mas também considerar o que aconteceu aos próprios textos: o que foi mantido, transformado, retirado. À medida que o Gótico se torna algo a ser mostrado visualmente na Espanha do século $X X$, nós observamos, por parte dos cineastas, um desejo semelhante de adaptar as imagens do modo para públicos novos e modernos: os subtextos eróticos do Gótico vêm à tona em 1960 e 1970, um período de mudanças dramáticas para a Espanha e de abertura cultural gradual. Este é o meu segundo ponto, a saber, o fato de que o modo realista é considerado como o registro literário preferido do país é, em si, uma construção crítica que, talvez, algumas vezes mascare certo conservadorismo. O Gótico, sobretudo, em sua representação lúdica do numinoso e do sobrenatural, evidentemente possibilitou a exploração de ideias que, de outro modo, permaneceriam tabus. O caso de Alfonso Sastre, cuja obra frequentemente foi muito política e frustrada por intervenções da censura, é um bom exemplo.

P.: Na introdução de Horror: A Literary History, você se refere ao horror como o gênero par excellence porque ele explora estados emocionais negativos "como terror, choque ou repulsão abjeta (p.12)" em nível pessoal e/ou social. Você 
poderia falar mais sobre esta característica do horror, e qual a diferença entre horror e gótico?

R.: A distinção entre o modo Gótico e o gênero de horror é uma distinção que eu tenho tentado resolver desde que escrevi as linhas citadas na pergunta. Acho que fiz um trabalho um pouco mais completo na introdução de Gothic Cinema (2020) e em um artigo que escrevi no ano passado para a Oxford Research Encyclopedia of Literature ${ }^{6}$. Em poucas palavras, porém, eu acredito que "horror" seja um gênero definido pelo estado emocional que ele busca engendrar; em linhas gerais, "horror" ou "medo". Neles, há subcategorias: alguns textos querem inquietar de um modo menos agressivo, por exemplo, ao sugerir, em vez de descrever, a fonte da ameaça; outros vão confrontar leitores e personagens diretamente ou focar na dor e na carnificina, e ainda há aqueles que vão enfatizar o lado repulsivo do medo. O horror, essencialmente, pode se manifestar em qualquer parte e a qualquer momento: é possível ter textos de horror no espaço, no Velho Oeste ou no fundo do mar. Ao contrário, o Gótico é mais ligado a uma época e a um local específicos, em geral, uma projeção fantástica do passado. Seus marcadores temporais, frequentemente associados à decadência, estagnação e retorno, são cruciais para o tipo de trabalho que ele realiza (ver adiante). O Gótico pode ser facilmente compreendido como uma fase da ficção de horror que perdurou até o presente (por essa razão, fala-

5 Link para a página do livro: https://www.routledge.com/Gothic-Cinema-1st-Edition/ Aldana-Reyes/p/book/9781138227569

6 Link para a página do artigo: https://oxfordre.com/literature/view/10.1093/ acrefore/9780190201098.001.0001/acrefore-9780190201098-e-187?rskey=xFSelf\&result=1 
se em "horror gótico"). O fato de que muitos dos filmes de horror clássicos da Universal e da Hammer tenham se inspirado em textos literários góticos confundiu ainda mais as coisas. Agora ambos compartilham muitos elementos da cartilha de atmosfera (tempestades, atmosferas), personagens (tiranos, monstros sobrenaturais) e motivos (assombrações, textos proibidos ou encontrados). Ainda assim, eu acho que eles podem ser produtivamente separados. Sei que não é necessariamente a definição mais popular do Gótico, que cada vez mais é visto como o lado sombrio da cultura e como algo que engloba qualquer coisa, do horror à ficção científica sombria, e mesmo à fantasia. No entanto, eu a considero uma taxonomia mais intuitiva, que nos permite separar estética de efeitos artísticos.

O horror, como uma forma artística sombria que explora isso que normalmente não é reconhecido, os tabus, aquilo que é rejeitado, reprimido ou temido, é, por sua natureza mesma, um dos gêneros artísticos mais honestos; eu diria até que é um dos mais humanos. Estudar a história do gênero de horror é pensar através de preocupações societárias que atravessam gerações para identificar um deslocamento de temores atavísticos e religiosos para, mais recentemente, os desafios criados pelo neoliberalismo, a ascensão da extrema direita ou a crise climática. Quanto ao Gótico, acredito que sua obsessão com o passado, sobretudo seu retorno traumático na forma de maldições, alucinações e até doenças hereditárias, me parece algo que explora naturalmente as cicatrizes de traumas nacionais e pessoais. Desde Usher até as aparições 
frequentemente indeterminadas associadas a objetos antigos em M. R. James e até os horrores da Guerra Civil espanhola no cinema de Guillermo del Toro, a linguagem da repressão e do reconhecimento, da restituição e da vingança, se presta ao exorcismo de fantasmas pessoais e à reparação nacional. A retrojeção do Gótico nos períodos vitoriano ou eduardiano ou em edificações substitutas sinaliza as tensões entre o que frequentemente interpretamos como o passado bárbaro, especialmente em termos de conflitos sociais, e o presente mais moderno. O gótico feminino canaliza essas preocupações particularmente bem: o castelo e a mansão góticos costumam representar noções ossificadas de patriarcado, um modo opressivo de controle que a heroína deve compreender e do qual deve encontrar um meio de escapar.

P.: Em The Gothic Body: Sexuality, Materialism, and Degeneration at the Fin de Siècle, de 1997, Kelly Hurley fala sobre um ressurgimento cíclico do gótico em períodos de crise social e epistemológica. Mais de vinte anos após o lançamento do livro, estamos vivendo um período de crise. Em sua opinião, também estamos testemunhando uma reemergência do Gótico? Que formas ele está assumindo?

R.: Maisha Wester e eu recentemente tentamos lidar com esta imensa questão em uma antologia intitulada Twenty-FirstCentury Gothic: An Edinburgh Companion (2019)', na qual nós olhamos para o Gótico contemporâneo de vários ângulos pertinentes. O aspecto transnacional do Gótico, do qual eu já

7 Link para a página do livro: https://edinburghuniversitypress.com/book-twenty-firstcentury-gothic.html 
falei, e que, portanto, vou deixar de lado agora, é importante, mas outros aspectos que nós consideramos relevantes são a capacidade do Gótico de mediar ansiedades em relação às mudanças climáticas e o impacto do comportamento humano sobre o ambiente (Ecogótico), em relação ao status e ao lugar do humano em uma época definida por desenvolvimento tecnológico em alta velocidade (Gótico pós-humano), novas plataformas digitais e comunicação instantânea (Gótico digital) e livre economia de mercado descontrolada (Gótico neoliberal). Os monstros do Gótico se adaptaram para levar a cabo este tipo de trabalho cultural também, então se poderia afirmar que o zumbi e o vampiro agora transmitem mais facilmente medo em relação ao perigo de pandemias em um mundo hiperconectado ou aos modos pelos quais certos corpos e comunidades continuam a ser socialmente abjetos. Sem dúvida, esta antologia se baseia em uma compreensão mais ampla do modo Gótico - que eu apontei na resposta anterior -, pela qual o Gótico se torna um meio para canalizar preocupações sociais, políticas, econômicas e ecológicas. Acho que o que parece inegável é o fato de que, após um período relativamente quieto nos anos de 1990, o Gótico voltou com força total no século XXI. Algumas pessoas, sem dúvida, lerão isso como uma resposta a importantes eventos históricos como os ataques terroristas ao World Trade Center e à crise econômica de 2008. Eu concordaria em parte, mas também acredito que o Gótico volte por causa das forças de mercado associadas à globalização e a modismos bemsucedidos - basta pensar, por exemplo, no surgimento de 
romances paranormais após o sucesso de Twilight [Crepúsculo] e de suas adaptações cinematográficas.

P.: Você acabou de lançar Gothic Cinema. Poderia falar sobre o livro? Você vê uma evolução do Gótico nas narrativas visuais das últimas décadas? E de que modo estas narrativas põem em questão a tradição do Gótico?

R.: Meu objetivo com o projeto que culminou em Gothic Cinema foi precisamente fazer uma defesa do cinema Gótico como modo estético, com um conjunto distintivo de marcadores que podem ser separados do horror. Ele foi mais ativamente impulsionado pela especificidade do meio cinemático e da indústria cinematográfica ocidental: quando o Gótico começou a se manifestar na tela, e será que isso foi um processo autoconsciente? Quando e por que o cinema começou a se inspirar, e até a criar, uma estética gótica comparável à da tradição literária? Monstros ou o sobrenatural são um requisito do gótico? Se antigamente ele era um mundo de sombras, o que foi que aconteceu ao cinema gótico quando a Hammer e outros estúdios começaram a imergir seus filmes de época num tecnicolor glorioso? E o que aconteceu ao gótico quando o boom de exploitation das décadas de 60 e 70, e o sucesso do horror mais realista e contemporâneo, popularizado pelo Exorcista, de 1973, tornaram seus cenários e subtextos eróticos antiquados e até mesmo redundantes? O impulso histórico por trás dessas perguntas urgentes foi significativamente fortalecido por uma bolsa que eu recebi da British Academy e do Leverhulme Trust, em 2018, para visitar os principais arquivos cinematográficos dos EUA - a Biblioteca 
do Congresso, em Washington, e a Margaret Herrick Library, em Los Angeles - e consultar o material fotográfico existente de muitos filmes góticos perdidos das décadas de 1910 e 1920 .

Eu só comecei realmente a escrever o que se tornaria Gothic Cinema, em 2016, mas seu período de gestação é bem anterior. Eu tive uma longa fascinação acadêmica com o Gótico desde o mestrado e, posteriormente, o doutorado e, claro, agora eu faço parte do Manchester Centre for Gothic Studies e leciono disciplinas sobre o Gótico na graduação e no mestrado, na Manchester Metropolitan University. De certa forma, pensar o cinema Gótico é algo que eu não posso deixar de fazer semanalmente. Ainda assim, dois momentos foram decisivos para o estalo criativo final. 0 primeiro foi um convite que recebi para fazer uma apresentação na temporada gótica no $\mathrm{BFI}$, em 2013. Quando os organizadores me perguntaram se eu tinha um livro sobre o tema, que eles pudessem divulgar, eu me dei conta de que provavelmente poderia e, com certeza, deveria ter. $\mathrm{O}$ segundo impulso veio quando eu dividia o curso "Introdução ao Cinema Gótico" com a Profa. Dra. Linnie Blake, em Cornerhouse (hoje HOME), no outono de 2014. A experiência foi transformadora e a empolgação dos participantes foi realmente contagiosa. Mais uma vez eu respondia negativamente quando as pessoas me perguntavam se eu tinha escrito algo sobre o tema do qual acabara de falar e, mais uma vez, pensei comigo mesmo que não havia uma boa razão para isso. Corta para 2020, e agora eu escrevi esse livro. Parte da escrita acadêmica, porém, é nunca estar totalmente satisfeito com o que foi escrito, por isso, eu tenho outros 
projetos associados que estou ansioso para desenvolver. Este é a minha primeira, mas não certamente a última (se eu tiver saúde para isso), palavra sobre a relevância do Gótico como uma estética cinemática.

P.: Você também editou as obras de H. P. Lovecraft, William Hope Hodgson e Algernon Blackwood, entre outros. Como você seleciona os contos para os livros? Você poderia descrever o seu processo de trabalho como editor de antologias de ficção?

R.: Eu tenho que observar que, na maior parte das vezes, eu selecionei e não editei, em sentido estrito, a obra desses autores. Sou um grande admirador de Lovecraft, Hodgson e Blackwood, mas simplesmente não tenho o conhecimento específico dos autores que, por exemplo, alguém como S. T. Joshi tem, e que é necessário para realmente editar a ficção deles. No entanto, eu acredito que o trabalho de editores de antologias é muito importante. No meu caso, por exemplo, fui apresentado às obras de muitos autores góticos e de horror através de coleções organizadas por pessoas como Stephen Jones e Mike Ashley. Quando são bem feitas, as antologias podem ser livros importantes.

Quando a The British Library me perguntou sobre a possibilidade de editar Lovecraft, eu não pensei duas vezes. Ele sempre foi um dos meus autores favoritos e eu senti que havia uma oportunidade de oferecer alguma coisa diferente ao me concentrar nos contos mais góticos. Hodgson e Blackwood, assim como Promethean Horrors: Classic Tales of Mad Science 
foram sugestões minhas como sequências que se encaixariam na série "Tales of the Weird", da qual sou um ávido seguidor. A minha ideia por trás das antologias sempre foi oferecer algo que, no fundo, é introdutório (por isso eu sempre opto por meus contos favoritos ou histórias que eu acho que merecem mais crédito) e um pouco diferente. Isso foi particularmente importante em relação à antologia dos cientistas loucos: eu queria criar o livro que eu sempre quis comprar, uma coleção com os melhores contos sobre cientistas loucos, mas que eu nunca encontrei. Na pior das hipóteses, essas antologias oferecem informações introdutórias acessíveis sobre escritores que poderiam ser uma novidade para muita gente. Um dos prazeres do meu trabalho como professor é apresentar aos alunos novos textos que, de outra forma, talvez eles nunca encontrassem, então vejo meu trabalho como editor de antologias como uma extensão disso.

P.: Como um dos membros fundadores do Manchester Centre for Gothic Studies, você poderia nos contar alguma coisa sobre o Centro, suas atividades e planos para o futuro?

R.: O Manchester Centre for Gothic Studies, fundado em 2013, é um hub de pesquisa que se concentra em manifestações variadas do modo Gótico, desde sua cristalização na literatura em fins do século XVIII até videogames modernos e outras formas de cultura popular. Nossa missão é promover o estudo do Gótico nacional e internacionalmente e trabalhar com diferentes faixas etárias e níveis de formação, do ensino médio ao doutorado e além. Para isso, nós organizamos intensivões, seminários de escrita criativa e cursos de Desenvolvimento 
Profissional Continuado. Organizamos festivais góticos por toda a cidade, dias de networking e palestras sobre pesquisas, frequentemente em colaboração com vários parceiros em Manchester e no Reino Unido, que nos ajudam não apenas a apresentar o nosso trabalho, mas também a levar os prazeres sombrios da cultura gótica para uma audiência não especializada mais ampla. Em 2018, sediamos a 14ª . Conferência da International Gothic Association, a reunião mais importante de pesquisadores do Gótico no mundo. Também criamos uma nova plataforma digital, HAUNT Manchester, que se concentra na oferta cultural sombria da cidade.

O nosso foco no futuro é continuar a ampliar o alcance internacional através de nossas atividades e colaborações. O festival Gothic Manchester acontecerá, pelo oitavo ano consecutivo, no mês de outubro (infelizmente não posso dar detalhes sobre o conteúdo a essa altura) e HAUNT Manchester começará a se expandir para outras cidades em breve. Isso é muito empolgante! Quanto a mim, vou oferecer um curso público de oito semanas com HOME cinema, em Manchester (de janeiro a março de 2020), para divulgar a publicação de Gothic Cinema e organizar uma campanha on-line usando a hashtag \#gothiccinema366 no Twitter (meu nome de usuário é @XaldanaReyes). A minha intenção é tuitar sobre um filme gótico diferente, incluído no livro, durante todos os dias do ano. Com sorte, eu vou conseguir falar de todos!

P.: Xavier Aldana Reyes, nós gostaríamos de agradecer por você ter respondido às nossas perguntas. Você gostaria de compartilhar mais alguma coisa com os leitores? 
R.: Não, acho que já tomei muito do tempo deles! Eu apenas queria agradecer a eles pela leitura e agradecer a vocês por esta entrevista incrível e pela pesquisa feita. Foi um prazer imenso da minha parte. Muito obrigado! 